\title{
Sustainable growth and strategies in the sea- faring industry
}

\author{
Aneta Oniszczuk-Jastrząbek ${ }^{1,}{ }^{*}$, Tomasz Czuba $^{1}$, and Ernest Czermański ${ }^{1}$ \\ ${ }^{1}$ University of Gdańsk, Faculty of Economics, 119/121 Armii Krajowej St., 81-824 Sopot, Poland
}

\begin{abstract}
The sustainable growth policy is the main driving force behind changes taking place under the European Union's common economic policy, particularly where this relates to transport policy. In the last decades, the sustainable growth policy has considerably expanded its reach as it has been implemented in various areas of economic and social life. Sustainable growth has also found its application in the sea-faring enterprises which are becoming increasingly aware of benefits to be gained through correlating their social commitment with their strategic goals. The drive towards promoting mutual trust and transparency both on the inside and outside is today becoming a way for these enterprises to achieve a competitive edge.

Despite voluntary action taken by businesses, including sea-faring ones, to build responsible relations with their stakeholders, the extent to which the ideas of sustainable growth are being applied in their formal operational strategies still leaves much to be desired.

The purpose of this paper is to determine the level of activity for sustainable growth seen in sea-faring companies operating in Poland. This article is based on a study of primary research including interviews with representatives of sea-faring enterprises and contains the authors' own reflections on the subject. The research relates to action which the enterprises in question are taking to integrate their policies, strategies and operational plans with sustainable growth.
\end{abstract}

\section{Introduction}

The enterprise management process in the contemporary world requires making a number of decisions on a strategic level. The ultimate goal of these decisions is the improvement of competitiveness of business entities and also the competitiveness of the countries in which they operate. The necessity to introduce changes - essential in the aspect of broadly defined competitiveness - and doing that quicker than competitors, must be considered in enterprise management.

Over the last years, the interest in the concept of sustainable growth has increased, which is followed by the changes in the attitudes and expectations of all market participants, including sea-faring enterprises. These companies must perform activities that lead to reasonable profit by pursuing the ideas of sustainable development.

\footnotetext{
*Corresponding author: ekoao@ug.edu.pl
} 
The growth of an enterprise is determined by the actions facing the social needs as well as those reaching beyond such needs in the aspect of general life improvement, especially given the fact that sea-faring enterprises are social entities, operating in the society at a certain level of civilizational achievement and development. The internal activities of a sea-faring enterprise, based on the common effort of its employees, as well as external activities, encompassing its relations with a broader environment, are also social, as the effects of the activity are socially verified.

A sea-faring enterprise should satisfy the needs of the consumers, thus while attempting to develop a product, it bears the sole responsibility for its quality, reliable information concerning that product and all that may happen in the course of its use. The other way round, every buyer of the product must be sure that it would not fail and that the responsibility lies with the company.

\section{The essence of the sustainable growth concept and its place in the enterprise strategy}

The literature gives a lot of definitions of enterprise strategy. It is difficult to judge who introduced that term to the economic sciences. Among the first to use it was A.D. Chandler [1], who defined strategy as a certain pattern of organisation [2]. That definition was further developed by $\mathrm{C}$. Hayden, who described it as an approach consisted in using the resources in the environment determined by the competitors in a way allowing to fulfil a set of goals of the organisation [3]. Currently enterprise strategy is perceived in various ways:

- $\quad$ as a sequence of specific events or actions [4],

- $\quad$ as the focus on directions of corporate growth [5],

- as a set of coordinated methods of reaching goals [6],

- as a system of values allowing the identification and assessment of opportunities and threats, that enables to take actions to ensure long-term existence [7],

- as a programme of action, determining the major goals of the organisation along with the methods of fulfilment [8].

The strategy of each enterprise is a compromise agreed between different groups of stakeholders, taking into account its goals, responsibility and restrictions. Therefore the maturity of a socially accepted company is reflected in sustainable creation, fulfilment and control of the activity, driven by a vast set of expectations. As a result, the enterprise must be able to resolve conflicts between individual parties, that quite often emerge on the grounds of opposite expectations [9]. Thus, the model of sustainable growth of an enterprise assumes that there is a balance between three equally important components: economic, ecological and social, that affect each other and interact. One of the elements of reaching this balance is the enterprise activity to improve the condition of the natural environment and social responsibility [10].

Sustainable growth is related with a number of rules that have effect on the activity of enterprises and that should satisfy the current needs without affecting the capability to satisfy the needs of future generations, combining the aspiration to achieve economic prosperity, protection of natural environment and maintaining social equality [11]. Art. 3, item 50 of the Act of 27 April 2001 Environmental Protection Law contains the following definition of sustainable growth: “(...) social and economic development, in which the process of integration of political, economic and social actions takes place, keeping natural balance and sustainability of basic natural processes, in order to guarantee the possibility to satisfy basic needs of individual societies or citizens, belonging both to the contemporary and future generations" [12]. 
Common access to information causes that consumers are more interested in the activity of enterprises. They want to know if companies produce in a socially responsible manner. The society of knowledge requires enterprises to be fair, responsible for their activity and sensitive to social needs. The employees' attitude towards work undergoes changes as well. They are better-educated, demand better information and want to participate in taking organisational decisions, which is followed by higher motivation, increased commitment, better initiative and identification with the enterprise. It must be pointed out that employees of a given enterprise are also consumers of its products. The ongoing changes in business environment are reflected in the awareness of entrepreneurs, who more often recognise the value of ethical behaviour and the significance of trust in terms of the success of their enterprise [13].

The strive of an enterprise to reach the balance between the economic, social and ecological value should be considered in an internal and external dimension. The internal aspect concerns the corporate management method, while the external one - the relation between the natural environment as well as the actions towards business partners, suppliers, customers, investors and social communities [13].

Sustainable growth of the enterprise should be incorporated both in the operating activities and business management strategy. The strategy must encompass the introduction of the socalled Socially Responsible Investment to the tangible assets of the enterprise, that would serve as a positive evidence of good enterprise management. Social investments have a longterm, thus strategic, character and are made in order to solve social problems. Their purpose is to create the grounds for sustainable and permanent growth of the community, and they are performed in partnership with public authorities and non-governmental organisations [14, 15].

J. Żurek has clearly emphasised that "incorporating specific tasks in the strategy of the enterprise activity in the social field is followed by introducing these task to the management area, which requires close correlation with the other goals and tasks in other fields of management" [16]. Consequently, it is desirable that the idea of sustainable development applies to all levels of management and is focused on fulfilment of strategic goals. It starts with creating a mission of the enterprise and ends with monitoring of the set goals. Sustainable growth at a general level concerns the direction of strategic activity of the enterprise as a whole, that is specifying the goals and methods of fulfilment. Depending on the goal, various strategies are created at the operating level, determined by the mutual relations with the environment, and at the functional level, facilitating management of individual functions of the enterprise [17].

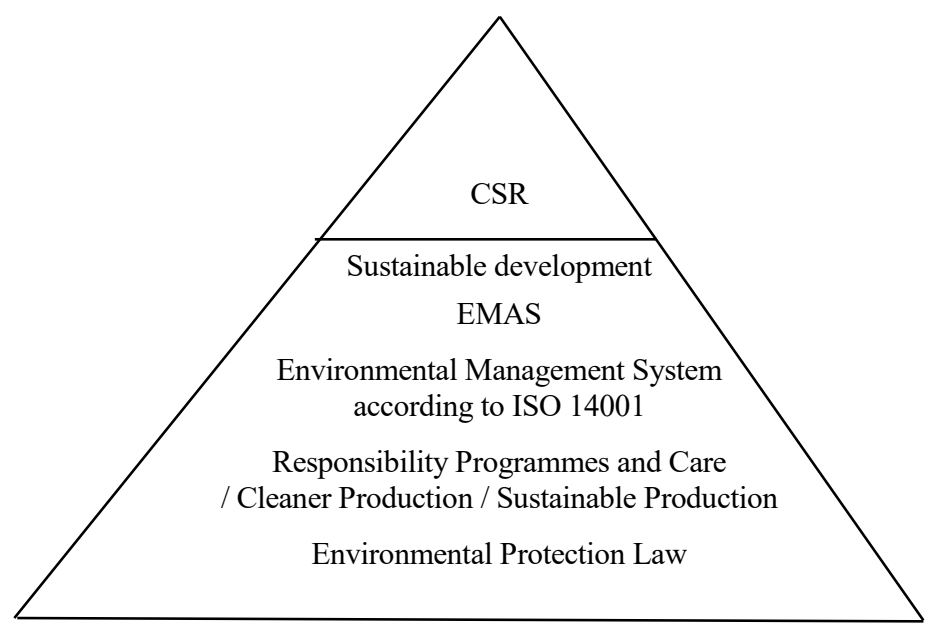

Fig. 1. Hierarchy of Corporate Social Responsibility in the aspect of sustainable growth [19]. 
According to A. Samborski, corporate social responsibility should be perceived as a business strategy that makes it easier to reach the goals (being more transparent), which consolidates the positive view of a socially responsible enterprise [18].

The hierarchy presented in Fig. 1. shows individual stages of enterprise improvement in terms of fulfilment of ecological, social and economic priorities. The top level is corporate social responsibility (CSR), being the excellence in the social activity.

Enterprise should be perceived as an integral part of the society, not as a solely economic institution. Thus the entity should increase the social benefits resulting from its operation, e.g. by offering employment or producing goods and services that satisfy the social needs. Corporate responsibility requires the enterprises to meet the ethical, social and ecological standards and values that must be recognised along with the activity increasing the enterprise profitability, including effective management of the possessed production factors. It is critical that the current economic goals are not preferred to the long-term social goals.

In the microeconomic scale, the implementation of the sustainable growth strategy is reflected in the fulfilment of that idea in a global field. So applying the idea of sustainable development by the largest possible number of organisational units is essential in the global aspect [20].

\section{Purpose and methodology of the survey}

In order to verify the functioning of the sustainable growth idea in the practical aspect in the strategy of sea-faring enterprises, an empirical survey has been conducted among those companies. The major goal of the survey was to determine the method of functioning of the sustainable growth idea in sea-faring enterprises. The survey was performed in June 2018 in a group of 25 sea-faring enterprises from Poland. The database of all companies representing that branch contained 44 records, out of which 34 entities were contacted and 25 of them finally replied. The survey was conducted using the CATI method and the questionnaire contained 11 questions. Telephone interviews (CATI) took no more than 15 minutes. 25 survey participants constituted $57 \%$ of all sea-faring enterprises in Poland.

\section{Survey results}

The concept of sustainable development was known by the representatives of $88 \%$ of the surveyed sea-faring enterprises (22 survey participants), $8 \%$ ( 2 companies) replied that the concept was new to them, while 1 survey participant (4\%) could not answer that question, claiming to be unsure.

The companies already familiarised with the sustainable growth concept $(n=22)$ indicated that its most important aspects (Fig. 2) were: focus on the interests of employees $(52 \%)$, good relations with employees, business partners, customers $(35 \%)$ and respecting the legal regulations, standards and human rights (30\%). The least important aspects listed by the survey participants included: company reputation $(9 \%)$, focus on quality and safety of products and services $(9 \%)$ and care for the workplaces $(9 \%)$.

The majority of sea-faring enterprises familiarised with the concept of sustainable growth $(\mathrm{n}=23)$ claimed that they performed activities related with sustainable growth. It is a good result and a strong point of the Polish sea-faring enterprises. Additionally, the survey participants reported that the fulfilment of the rules of sustainable growth in their enterprises was at a very good (35\%) or good level (40\%). $25 \%$ of the surveyed had no opinion on that issue. Furthermore, $70 \%$ of the asked representatives of sea-faring 


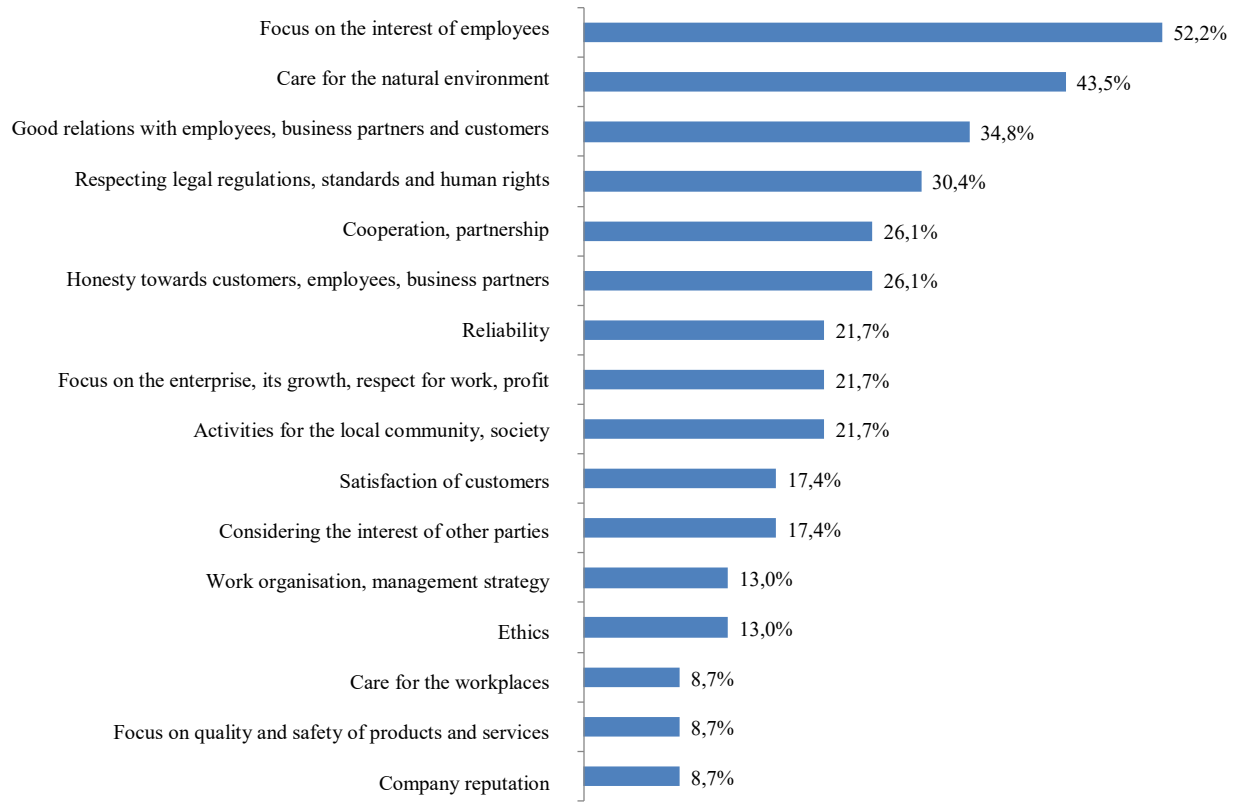

Fig. 2. Most important aspects of sustainable growth, indicated by survey participants $(n=23)$.

enterprises indicated benefits from applying the rules of sustainable growth. The most important ones included (Fig. 3.): positive reputation (74\%), good relations with the employees (44\%) and motivated employees (30\%).

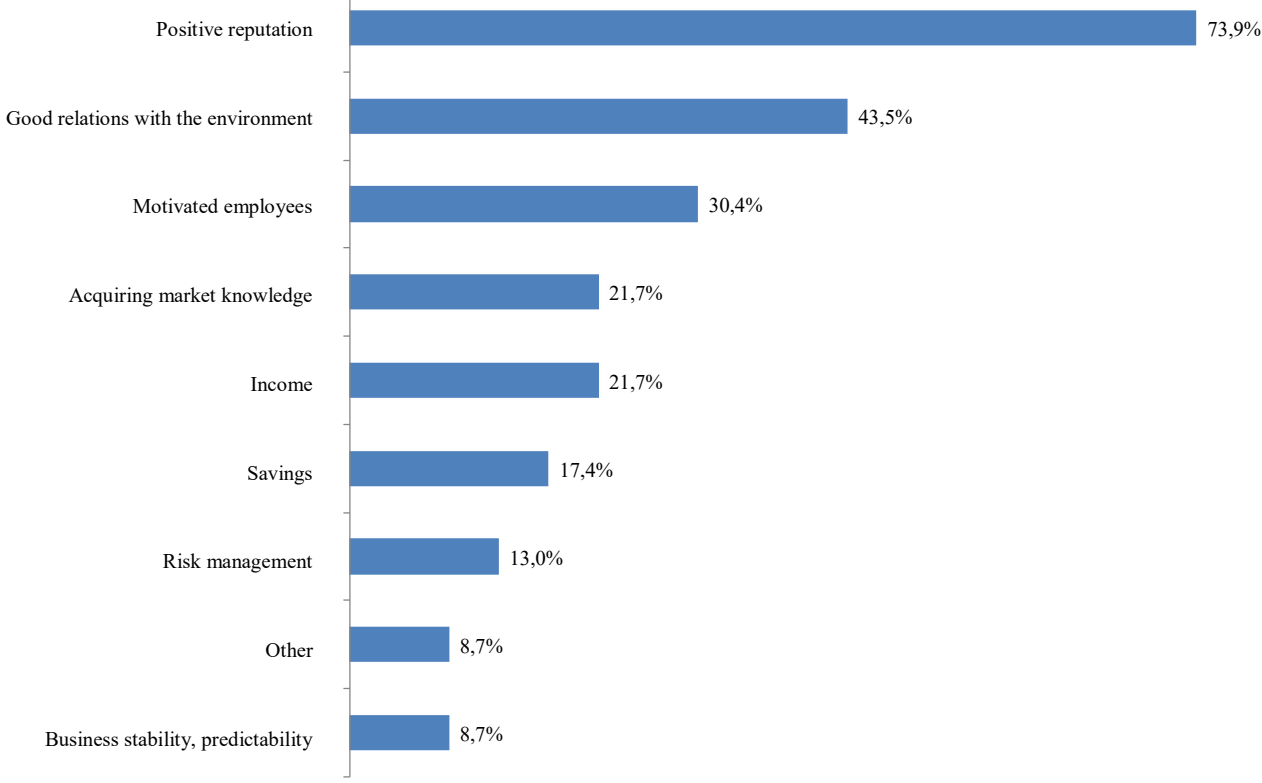

Fig. 3. Major benefits of the implementation of sustainable development rules, indicated by survey participants $(\mathrm{n}=23)$.

Survey participants indicated the following major problems in the implementation of the sustainable development rules in their enterprises (Fig. 4.): complexity of the subject 
(52\%), lack of knowledge and skills (44\%) and lack of involvement of the company management (39\%).

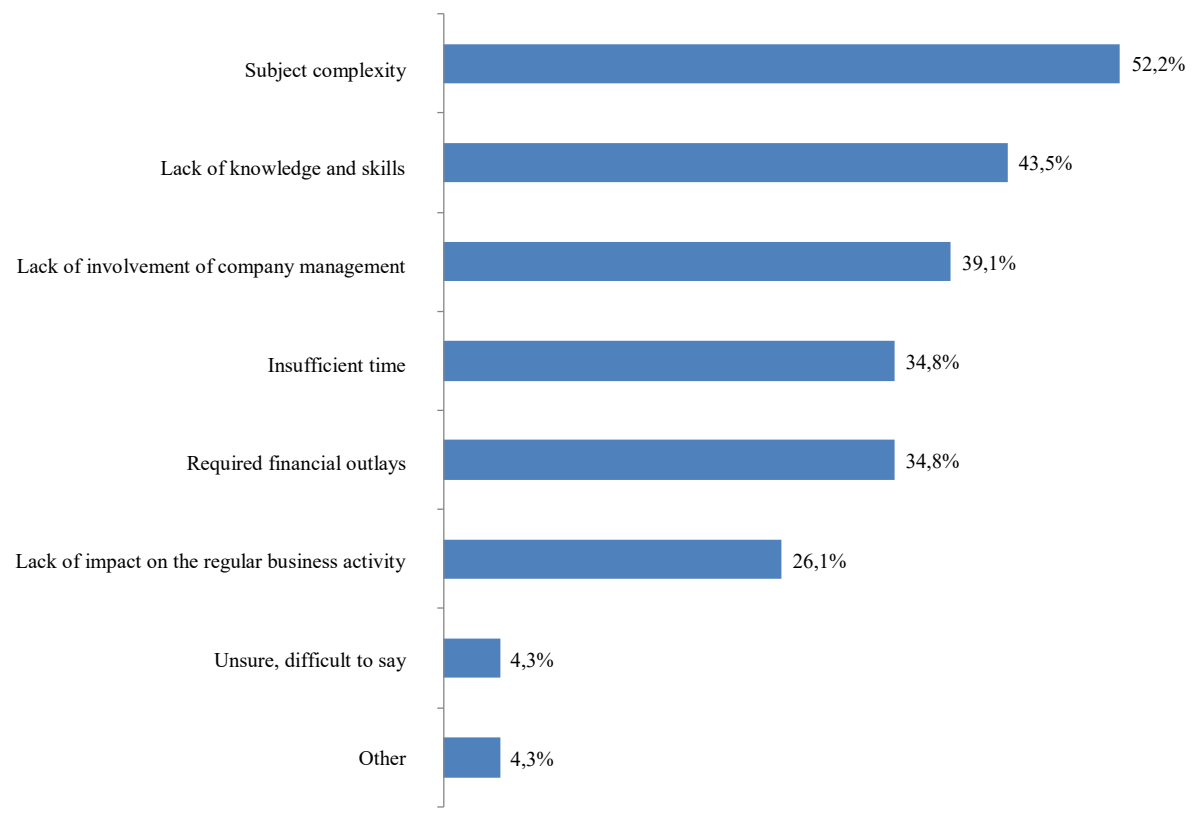

Fig. 4. Major problems in the implementation of sustainable development rules, indicated by survey participants $(\mathrm{n}=23)$.

According to the statements of the surveyed sea-faring enterprises:

- in $39 \%$ of entities, the mission, policy and goals included the aspects of sustainable growth,

- $35 \%$ of them implemented a specific strategy of sustainable growth,

- $\quad 17 \%$ prepared action plans including the aspects of sustainable growth and cooperated with - other entities in order to perform activities related with sustainable growth,

- $\quad 13 \%$ prepared to implement forms of cooperation with other entities in order to perform activities related with sustainable growth,

- $\quad 9 \%$ did not include the aspects of sustainable growth in the strategic elements of the enterprise.

- $65 \%$ of survey participants declared that the company mission was known by all employees. In the case of company vision that proportion reached only $44 \%$, while the code of conduct / ethical code was known in only $13 \%$ of sea-faring enterprises.

In the surveyed sea-faring enterprises, the documents concerning the mission, vision, enterprise value and other documents directly concerning the issues of corporate social responsibility mostly included the following aspects:

- relations with customers $-61 \%$ of replies,

- relations with the employees $-48 \%$,

- work organisation within the enterprise $-26 \%$,

- natural environment $-26 \%$,

- social commitment $-26 \%$,

- fair market practices $-17 \%$,

- human rights $-9 \%$.

The participants of the described survey planned to increase their commitment in the following fields within the 12-months period: 
- relations with the employees $-48 \%$,

- relations with customers $-30 \%$,

- natural environment $-30 \%$,

- fair market practices in relations with business partners $-26 \%$,

- work organisation within the enterprise $-17 \%$,

- activity for the benefit of local communities $-17 \%$,

- human rights $-9 \%$.

\section{Conlusions}

The awareness of the measurable benefits of the close correlation between the social commitment and strategic goals is increasing among sea-faring enterprises. The drive towards promoting mutual trust and transparency both on the inside and outside of the organisation, has become a way to run business and achieve a competitive edge.

Including social responsibility issues in the strategy of a sea-faring enterprise allows to see the future risks and make use of the opportunities that could never be discovered. Thus, including corporate social responsibility in the enterprise development strategy forces the company management to know the CSR rules and procedures and involve in the dialogue with all stakeholders. The ability to formulate a long-term strategy for development and consolidation of corporate social responsibility becomes indispensable, which also requires a broad social support, including close cooperation with the local community and local institutions.

Even though sea-faring enterprises voluntarily take various initiatives to build responsible relations with their stakeholders, the degree of popularisation and implementation of corporate social responsibility in formal operational strategies of companies in Poland is still considerably low.

\section{References}

1. B. Wawrzyniak, Polityka strategiczna przedsiębiorstw (PWE, Warszawa, 1989)

2. A.D. Chandler, Strategy and Structure. Chapters in the History of the Industrial Enterprises (MIT Press, Cambridge, 1972)

3. C. Hayden, The Handbook of Strategic Expertise (New York, 1985)

4. J. Kay, Podstawy sukcesu firmy (PWE, Warszawa, 1996)

5. H. Mruk, Strategie Marketingowe (Akademia Ekonomiczna w Poznaniu, Poznań, 2002)

6. Z. Pierścionek, Strategie rozwoju firmy (PWN, Warszawa, 1996)

7. K. Obłój, Strategia sukcesu firmy (PWE, Warszawa, 1998)

8. M. Romanowska, Strategie rozwoju i konkurencji (Centrum Informacji Menedżera, Warszawa, 1998)

9. A. Oniszczuk-Jastrząbek, O. Dębicka, Koncepcja zrównoważonego rozwoju a strategia przedsiębiorstwa - wyniki badań [w:] Przedsiębiorstwo w otoczeniu globalnym. Możliwości rozwoju. Red. A. Oniszczuk-Jastrząbek, T. Gutowski, (UG, Gdańsk, 2014)

10. H. Kruk, Konkurencyjność przedsiębiorstw w świetle zasad rozwoju zrównoważonego, [w:] Przedsiębiorstwo w otoczeniu globalnym. Red. O. Dębicka, A. OniszczukJastrząbek, T. Gutowski, J. Winiarski (UG, Gdańsk, 2009) 
11. M. Pigłowski M., Współczesne uwarunkowanie rozwoju zrównoważonego, [w:] Uwarunkowania rozwoju przedsiębiorczości. Determinanty $i$ narzędzia zdobywania przewagi konkurencyjnej. Red. H. G. Adamkiewicz-Drwiłło, (PWN, Warszawa, 2007)

12. Ustawa z dnia 27 kwietnia 2001 roku o wprowadzeniu ustawy - Prawo ochrony środowiska, ustawy o odpadach oraz zmianie niektórych ustaw, DzU, 2001, nr 100, poz. 1085, z póź. zm.

13. K. Kulig-Moskwa, Odpowiedzialność społeczna jako czynnik konkurencyjności przedsiębiorstw $w$ gospodarce opartej na wiedzy, [w:] Europejskie wymiary przedsiębiorczości. Red. Kruk H, Skrzeszewska (AM, Gdynia, 2008)

14. J. Nakonieczna, Społeczna odpowiedzialność przedsiębiorstw międzynarodowych (Difin, Warszawa, 2008)

15. M.L. Barnett, R.M. Salomon, Beyond Dichotomy: The Curvilinear Relationship Between Social Responsibility and Financial Performance, "Strategic Management Journal" 27, 1101-1122 (2006)

16. J. Żurek, Społeczna odpowiedzialność przedsiębiorstwa i jej wplyw na sukces rynkowy przedsiębiorstwa w gospodarce globalnej [w:] Przedsiębiorstwo w otoczeniu globalnym. Rozwój w warunkach niestabilności gospodarczej. Red. A. Oniszczuk-Jastrząbek, (Fundacja Rozwoju Uniwersytetu Gdańskiego, Gdańsk, 2011)

17. A. Oniszczuk-Jastrząbek, Przedsiębiorczość w budowaniu zdolności konkurencyjnej przedsiębiorstwa (Wydawnictwo Uniwersytetu Gdańskiego, Gdańsk, 2013)

18. A. Samborski, Przegląd Organizacji 1, 14-17 (2012)

19. M.K. Wyrwicka, D. Jaźwińska, Logistyka 3, 5853-5858 (2015)

20. D. Jaźwińska, Organizacja i Zarządzanie, 71, 161 (2016) 